\title{
ZINC CONTENT IN THE DIET AFFECTS THE EXPRESSIONAL CHANGES OF CU/ZNSOD IN AORTA OF SPONTANEOUSLY HYPERTENSIVE RATS
}

\author{
A. Dimitrova ${ }^{1}$, D. Strashimirov ${ }^{1}$, T. Betova ${ }^{2}$, A. Russeva ${ }^{3}$, M. Alexandrova ${ }^{4}$, M. \\ Apostolova 5 \\ ${ }^{1}$ Medical University, Dept. of Pathophysiology, Pleven, Bulgaria, ${ }^{2}$ Medical University, Dept. of \\ Pathoanatomy, Pleven, Bulgaria, ${ }^{3}$ Medical University, Dept. of Clinical Laboratory, Pleven, \\ Bulgaria, ${ }^{4}$ Medical University, Dept. of Biophysics, Pleven, Bulgaria, ${ }^{5}$ Institute of Molecular \\ Biology, Lab Med \& Biol Res, Sofia, Bulgaria
}

Reviewed by: Assoc. Prof. N. Negrev, MD, PhD

\section{SUMMARY}

Oxidative stress induced by reactive oxygen species (ROS) plays an important role in development of hypertension. Vascular cells have a complex antioxidant system for protection against increased oxidative stress. Zinc is a cofactor of one of the most important antioxidant enzyme - copper-zinc superoxide dismutase (Cu/ZnSOD). The aim of the present study was to examine the effects of feeding different $\mathrm{Zn}$ containing diets $(40,60,160 \mathrm{mg} \mathrm{Zn} / \mathrm{kg}$ lab chow) on the activity and expression of $\mathrm{Cu} / \mathrm{ZnSOD}$ in aorta of male $(\mathrm{n}=27)$ spontaneously hypertensive rats (SHR). The diets were introduced at the beginning of the development of hypertension ( 2 months after birth) and the animals were fed for 8 weeks. Cu/ZnSOD expression was analyzed by immunohistochemistry and the activity was measured by RANSOD kit (RANDOX). Atomic-absorption spectrometry was used to determine $\mathrm{Zn}$ and $\mathrm{Cu}$ concentrations in the rat's sera. $\mathrm{Cu} / \mathrm{ZnSOD}$ was mainly expressed in medial smooth muscle cells and it had a weak immunoreactivity in the endothelium. In the group with $\mathrm{Zn}$ supplementation diet $(160 \mathrm{mg} \mathrm{Zn/kg} \mathrm{lab} \mathrm{chow),} \mathrm{Cu} / \mathrm{ZnSOD}$ staining was more enhanced in the smooth muscle cells and endothelium, and the systolic blood pressure was significantly decreased $(\mathrm{P}<0.05)$ in comparison with the groups fed with other $\mathrm{Zn}$ diets $(40$ or $60 \mathrm{mg} / \mathrm{kg}$ lab chow). The change in $\mathrm{Cu} / \mathrm{ZnSOD}$ activity correlates well with the protein expression and with the arterial blood pressure alterations. The present data suggest that $\mathrm{Zn}$ concentration in the diet may play an important role in the regulation of the blood pressure and may in part be a critical nutrient for maintenance of anti-oxidative events in the endothelial cells in SHR.

\section{INTRODUCTION}

Zinc is a critical component of biomembranes and is essential for proper membrane structure and function and the activity of numerous enzymes (Oteiza PL, 1996). It could conceivably limit oxidant-induced damage. Some possible antioxidant actions of zinc include: a) Stabilization of membrane structure (Di Silvestro R., 2000); b) Restriction of endogenous free radical production (Sakanashi TM, 1993); c) Contribution to the structure of the antioxidant enzyme extracellular superoxide dismutase (Miller AF., 2004); d) Maintenance of tissue concentrations of

\footnotetext{
Address for correspondence:

A. Dimitrova, Dept of Pathophysiology, Medical University - Pleven, Medical University, 1 St. Kl.Ochridski Str., 5800 Pleven, BULGARIA E-mail: nelly_pleven@abv.bg
}

metallothionein, a possible scavenger of free radicals (Cousins RJ., 1995).

It has been shown that $\mathrm{Zn}$ deficiency aggravates arterial blood pressure in SHR rats by decreasing $\mathrm{Cu} / \mathrm{ZnSOD}$ activity and increases lipid peroxidase, which is a binding segment between hypercholesterolemia and atherosclerosis (Khoja SM, 2002; Mertens A, 2001). There are also data indicating that changes in the serum zinc concentrations can alter CuZnSOD activity, cholesterol (Chol), and triglycerides (Tg) concentrations, and the level of mmLDL in rats (Yousef MI, 2002).

The present study focused on the effect of $\mathrm{Zn}$ containing diets on the activity and expression of $\mathrm{Cu} / \mathrm{ZnSOD}$, arterial blood pressure, lipid peroxides $(\mathrm{ROOH})$, lipid variables (LDL, HDL, triglycerides and cholesterol) in male SHR rats. 


\section{MATERIALS AND METHODS}

The investigation conforms to the Guide for Animal Care and Use of Laboratory Animals by the Ethical Committee of the Medical University, Pleven, Bulgaria

\section{Animals and diets}

Male spontaneously hypertensive rats (SHR, $\mathrm{n}=27$ ), with b.wt. $212.84 \pm 22.54$ were used. Animals were housed in groups of 5 per cage and kept under a normal $12 \mathrm{~h}$ light/dark cycle at $22^{\circ} \pm 2^{\circ} \mathrm{C}$. Rats were allowed access to food and water ad libitum. They were randomly divided into 3 groups: Group $1(\mathrm{G} 1, \mathrm{n}=10)$ - $40 \mathrm{mg} \mathrm{Zn} / \mathrm{kg}$ diet; Group 2 (G2, n=7) - 60 mg Zn /kg diet; Group 3 (G3, n= 10) - $160 \mathrm{mg} \mathrm{Zn/kg}$. The zinc diets containing different $\mathrm{Zn}$ amounts were introduced at the beginning of the development of hypertension ( 2 months after birth) and the animals were fed for 8 weeks.

Zinc content in the laboratory chow and serum concentration of zinc and copper were analyzed by a flame atomic-absorption spectrophotometry, using Perkin-Elmer, Model-Analyst 300 apparatus.

\section{Blood Collection and abdominal artery preparation.}

At the end of the treatment period, following overnight fasting, the abdominal cavity of rats was opened under pentobarbitone sodium anesthesia $(26 \mathrm{mg} / \mathrm{kg}$ body weight, i.p.). Blood was collected from the bifurcation of the aorta for the measurements of $\mathrm{Zn}$ and $\mathrm{Cu}$, SOD activity, lipid profile. The abdominal artery was post-fixed by immersion in $10 \%$ neutral buffered formalin (NBF) and embedded in paraffin.

\section{Immunohistochemistry}

Consecutive sections ( $5 \mu \mathrm{m}$ thick) of paraffin-embedded abdominal arteries were cut, and immunostained with goat anti-rabbit CuZnSOD (1:500 dilution, Santa Cruz Biotechnology, USA), antibody by using an avidin-biotin-peroxidase complex (ABC) method (DAKO, USA) for 30 minutes, according to the manufacturers' instructions.
All sections were counterstained with haematoxylin and examined by light microscopy OLYMPUS BX40.

\section{Chemical analysis}

\section{Assay of Cu/ZnSOD activity}

Following blood collection and centrifugation at $3000 \mathrm{rpm}$ for 10 minutes, the plasma was aspirated and the erythrocytes were rinsed four times with $3 \mathrm{ml}$ saline solution at $4^{\circ} \mathrm{C}$. Measurement of erythrocytes CuZnSOD activity was determined by RANSOD reactive photometric method (RANDOX, England).

\section{$\mathrm{Cu}-\mathrm{Zn}$ Superoxide dismutase measurement}

This method employs xanthine and xanthine oxidase (XOD) to generate superoxide radicals, which react with 2-(4-iodophenyl)-3-(4-nitrophenol)-5-phenyltetrazolium chloride (I.N.T.) to form a red formazan dye. The superoxide dismutase (SOD) activity is then measured (at $505 \mathrm{~nm}$ ) by the degree of inhibition of this reaction. One unit of SOD is that which causes a 50\% inhibition of the rate of reduction of INT under the conditions of the assay. Lipid analysis

Lipid analysis was performed on a Hitachi-704 automated clinical chemistry analyzer (Boehringer, Germany) with reagents from Horiba ABX Diagnostics (France). Total cholesterol was detected by enzymatic photometric test (CHOD-PAP, Horiba ABX Diagnostics, France). Triglycerides and HDL-cholesterol determinations were done following the manufacturer's instructions (Horiba ABX Diagnostics, France). The concentration of LDL was determined flowing the method described by Friedewald W.T. (1972).

$$
L D L=\text { total cholesterol }-H D L-\frac{\text { triglycerides }}{2.2}
$$

\section{Blood pressure determinations}

Blood pressure was determined by tail cuff plethysmography (Blood Pressure Recorder, Ugo Basile, Italy). Conscious rats were placed on a heated pad in a temperature-controlled quiet room. After a 15-min rest with the tail placed inside a tail cuff, the cuff was inflated three to four times to condition the animal to the procedure.

Table 1. Levels of $\mathrm{Zn}$ and $\mathrm{Cu}$, serum ROOH and Cu/ZnSOD activity in SHR fed a standard (G1), G2 and a Zn-supplement diet (G3) for 8 weeks.

\begin{tabular}{||c|c|c|c|c||}
\hline $\begin{array}{c}\text { Zn concentration } \\
\text { in the diet } \\
{[\mathbf{m g} / \mathbf{k g}]}\end{array}$ & $\begin{array}{c}\mathbf{Z n} \\
{[\mathbf{m m o l} / \mathbf{L}]}\end{array}$ & $\begin{array}{c}\mathbf{C u} \\
{[\mathbf{m m o l} / \mathbf{L}]}\end{array}$ & $\begin{array}{c}\mathbf{R O O H} \\
{[\mathbf{n m o l} / \mathbf{m l} \text { serum] }}\end{array}$ & $\begin{array}{c}\text { SOD activity } \\
{[\mathbf{U} / \mathbf{g} \text { Hg] }}\end{array}$ \\
\hline G1 - 40 & $18.92 \pm 0.43$ & $27.33 \pm 1.18$ & $4.61 \pm 0.31$ & $2049.1 \pm 257.7$ \\
\hline G2 -60 & $19.86 \pm 0.51$ & $26.16 \pm 1.29$ & $4.86 \pm 0.29$ & $2177.1 \pm 337$ \\
\hline G3 - 160 & $22.24 \pm 0.28^{*}, \#$ & $25.96 \pm 0.33$ & $3.48 \pm 0,08^{*}, \#$ & $3179.3 \pm 286.1 \#$ \\
\hline
\end{tabular}

Data reported represent means \pm S.E. of the values. *- $\mathbf{p}<0.05$; \# - $\mathbf{p}<0.001$

* - significant difference between G2 and G3; \# - significant difference between G1 and G3 


\section{Degree of oxidative damage}

The degree of oxidative damage was estimated by means of lipid peroxides $(\mathrm{ROOH})$ in serum following the procedures described by Yagi (1987).

\section{Statistical Analysis}

Results from biochemical assays were expressed as the mean \pm SE. The data were analyzed using one-way and two-way analysis of variance (ANOVA) when they were normally distributed, or with Kruskal-Wallis and medial test when they deviated from normal distribution. Descriptive statistics were used for immunohistochemical data, analyzing median, minimum, maximum and percentage. A value of $P<0.05$ was considered statistically significant.

\section{RESULTS}

\section{Effect of Zn treatment on the level of $Z n$ and $\mathrm{Cu}$, serum $\mathrm{ROOH}$ and $\mathrm{Cu} / \mathrm{ZnSOD}$ activity}

Table 1 shows data on the level of $\mathrm{Zn}$ and $\mathrm{Cu}$, serum ROOH and SOD activity in SHR fed a standard (G1) or a $\mathrm{Zn}$-supplement diets (G2 and G3) for 8 weeks. The Zn-supplement diet group (G3) had a significantly increased concentration of serum $\mathrm{Zn}$ relative to the standard diet group (G1). There was no significant difference in serum Cu concentration between the groups.

\section{Cu/ZnSOD activity}

The effect of $\mathrm{Zn}$ diets on CuZnSOD activity in the red blood cells was investigated to determine whether superoxide radicals in/and around arterial endothelia cells affect vascular resistance and blood pressure. Our result showed that the activity of $\mathrm{Cu} / \mathrm{ZnSOD}$ was higher in G3 and decreased in G1. There was a significant difference in the activity of $\mathrm{G} 3$ compared to $\mathrm{G} 1(\mathrm{p}=0.020)$. The data for activation of $\mathrm{CuZnSOD}$ correlated positively with the application of increasing $\mathrm{Zn}$ concentration in the diets $(r=$ $0.501, p=0,008)$.

\section{ROOH}

We monitored the level of serum $\mathrm{ROOH}$ and determined that it depended on the zinc diets. SHR rats treated with the lower Zn diet (G1) showed significantly increased concentration of serum lipid peroxides in comparison with animals treated with higher $\mathrm{Zn}$ concentration (G3, $\mathrm{p}=0.016$ ). We have also observed significant difference in the concentration of lipid peroxides between $\mathrm{G} 2$ and $\mathrm{G} 3(\mathrm{p}=0.005)$. The level of serum $\mathrm{ROOH}$ correlated negatively with the $\mathrm{Zn}$ concentration in the diets $(r=-0.512, p=0.015)$.

\section{Effect of Zn treatment on rat systolic blood pressure}

Table 2 summarizes the effects of $\mathrm{Zn}$ administration on systolic blood pressure (SBP) of SHR. All groups of SHR showed continues increase of systolic blood pressure fol- lowing the administration of different $\mathrm{Zn}$ containing diets, reaching significance on month 4 ( $p<0.001$, compare to SBP on month 2).

Table 2. Systolic blood pressure obtained from SHR fed a standard (G1), diet 2 - $60 \mathrm{mg} \mathrm{Zn/kg} \mathrm{and} \mathrm{a}$ $\mathrm{Zn}$-supplement diet (160 $\mathrm{mg} \mathrm{Zn/kg).}$

\begin{tabular}{||c|c|c||}
\hline \hline $\begin{array}{c}\text { Zn concentration } \\
\text { in the diet } \\
\text { [mg/kg] }\end{array}$ & $\begin{array}{c}\text { Blood pressure } \\
\text { (mm Hg) - Month 2 }\end{array}$ & $\begin{array}{c}\text { Blood pressure } \\
\text { (mm Hg) - Month 4 }\end{array}$ \\
\hline G1 - 40 & $175.1 \pm 2.21$ & $190.8 \pm 2.37^{*}, \#$ \\
\hline G2 - 60 & $169.85 \pm 3.7$ & $187.14 \pm 3.75^{*}$ \\
\hline G3 - 160 & $168.4 \pm 3.32$ & $178.8 \pm 1.79^{*}$ \\
\hline
\end{tabular}

Systolic blood pressure was measured as described in the Methods section.

${ }^{*} \mathrm{p}<0.001, \# \mathrm{p}<0.05 ;{ }^{*}$ - significant difference between month 4 and month 2; \# - significant difference between G1 and G3

Two months dieting with $\mathrm{Zn}$ at concentrations 160 caused blood pressure to be lowered significantly $(\mathrm{p}<0.01)$ compare to control group ( $40 \mathrm{mg} / \mathrm{kg}$ diet). These observations show that for $\mathrm{Zn}$ at concentrations $160 \mathrm{mg} / \mathrm{kg}$, the dosage and the duration of the regimen were effective in the obtaining a blood pressure decrease without severely compromising the health of the treated animals.

\section{Lipid profile}

Some investigators reported effects of zinc on lipid metabolism but the mechanism of action is not clear enough. The changes in serum total lipid values at 8 weeks after beginning of diet are given in Fig. 1. A significant decrease was observed in serum level of LDL $(p<0.05)$ in SHR fed a $\mathrm{Zn}$ diet 3 (G3), $(0.49 \pm 0.05)$ compared to SHR fed a $\mathrm{Zn}$ diet 1 (G1), $(0.68 \pm 0.04)$. No difference was found for triglyceride and total cholesterol between G1, G2 and G3. HDL was significantly increased in group 3 (G3), (0, 64 $\pm 0,06)$ in comparison with group 2 (G2), $(0.54 \pm 0.03$; $\mathrm{p}<0,05)$ and group 1 (G1), $(0.55 \pm 0.02 ; \mathrm{p}<0,05)$.

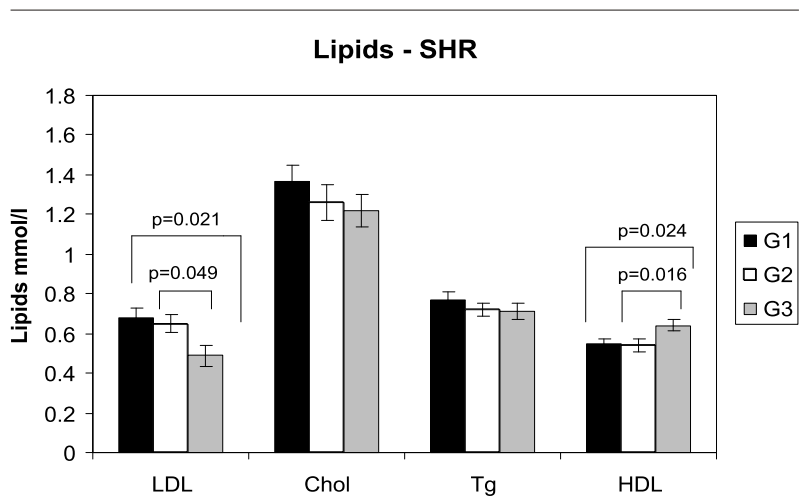

Fig. 1. Serum lipid profile in SHR fed a standard (40 $\mathrm{mg} / \mathrm{kg}$ ), diet 2 - $60 \mathrm{mg} \mathrm{Zn/kg} \mathrm{and} \mathrm{a} \mathrm{Zn}$-supplement diet (160 $\mathrm{mg} \mathrm{Zn} / \mathrm{kg}$ ).

Immunohistochemical protein localization of $\mathrm{Cu} / \mathrm{ZnSOD}$ 

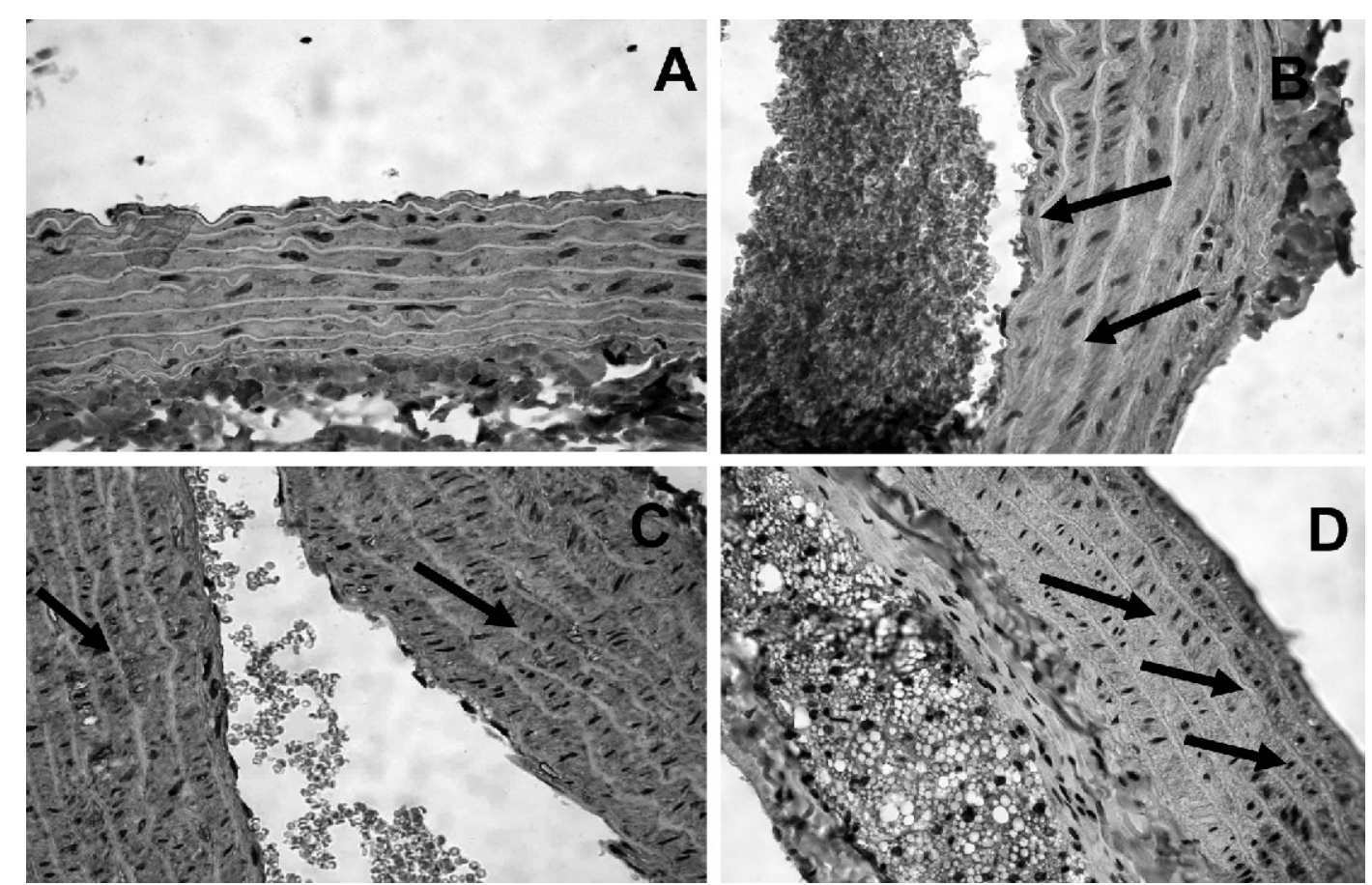

Fig. 2. Microphotograph of immunohistochemical $\mathrm{Cu} / \mathrm{ZnSOD}$ staining. (A) - $\mathrm{Cu} / \mathrm{ZnSOD}$ negative control. $\mathrm{Cu} / \mathrm{ZnSOD}$ was present in control group (diet with $40 \mathrm{mg} \mathrm{Zn/kg} \mathrm{lab} \mathrm{chow} \mathrm{-} \mathrm{G1)} \mathrm{(B)} \mathrm{and} \mathrm{in} \mathrm{G2-60} \mathrm{mg} \mathrm{Zn/kg} \mathrm{lab} \mathrm{chow} \mathrm{(C)} \mathrm{and} \mathrm{G3} \mathrm{-} 160 \mathrm{mg} \mathrm{Zn/kg} \mathrm{lab}$ chow (D). Magnification x 400.

To realize how different $\mathrm{Zn}$ diets effect the distribution of $\mathrm{CuZnSOD}$ in the endothelium, an immunohistochemical studies were performed with the abdominal aorta (Fig. 2.), following 2 months of treatment. Immunohistochemical examination of the $\mathrm{CuZnSOD}$ showed that $\mathrm{CuZnSOD}$ was expressed mainly in medial smooth muscle cells. was evaluated by immunohistochemistry. By immunohistochemistry, semiquantitative evaluation revealed that $\mathrm{Cu}, \mathrm{ZnSOD}$ was present in control group and groups with $\mathrm{Zn}$ supplementation, but its expression increased according to the zinc diets, reaching the highest level in G3 (Table 3).

Table 3. Quantification of Cu/ZnSOD expression in control group G1 and groups G2 and G3.

\begin{tabular}{||c|c|c|c|c||}
\hline \hline Group & mean \pm SE & Median (range) & \multicolumn{2}{|c||}{ Intensity1/ Percent (\%)2 } \\
\hline G1-40 mg Zn/kg & $1.30 \pm 0.15$ & $1.00(1.00-2.00)$ & 1 & 70 \\
\hline G2-60 mg Zn/kg & & & 1 & 30 \\
\hline & $2.00 \pm 0.27$ & $2.00(1.00-3.00)$ & 2 & 36.4 \\
\hline & & & 3 & 27.3 \\
\hline G3-160 mg Zn/kg & $2.5 \pm 0.15 \mathrm{a}$ & $2.50(2.00-3.00)$ & 3 & 50.4 \\
\hline
\end{tabular}

${ }^{\text {a }} P<0.05$ vs control. ( $n=7-10$ cases per group). ${ }^{1}$ The intensity of immunohistochemistry was graded blinded according to the following scale: 0 : absent, 1: weak, 2: moderate and 3 : intense. ${ }^{2}$ Percentage of samples according to degree of staining.

$\mathrm{CuZnSOD}$ had only week immunoreactivity in the endothelium following all treatments. CuZnSOD staining was increased with increasing of the $\mathrm{Zn}$ concentration in the diet.

To investigate the mechanisms leading to an increase of $\mathrm{SOD}$ activity in the red cells $\mathrm{Cu}, \mathrm{ZnSOD}$ protein expression

\section{DISCUSSION}

The function of zinc in the body metabolism is based on its enzymatic affinity, such as a zinc-enzyme complex or Zinc metalloenzyme. Zinc is a required cofactor for a variety of antioxidant enzymes, particularly superoxide dismutase 
There are varying reports on changes in plasma lipid peroxidation, zinc and erythrocyte $\mathrm{Cu}-\mathrm{Zn}$ supetoxide dismutase enzyme activity in SHR. Some of the studies reveal an increase, whereas others showed a decrease or no significant differences (Marjani A., 2005). There are a few reports describing differences in serum lipid peroxidation, zinc and erythrocyte $\mathrm{Cu}-\mathrm{Zn}$ superoxide dismutase activity between SHR versus controls (WKY).

The results of this study show that in SHR fed a $\mathrm{Zn}$ diet 3 (G3) serum lipid peroxidation was significantly decreased, and that zinc levels were increased compared to controls $(\mathrm{P}<0.05)$. This study also shows that the erythrocyte superoxide dismutase enzyme activity was increased in SHR fed a $\mathrm{Zn}$ diet 3 compared with controls $(\mathrm{p}<0.05)$.

$\mathrm{Cu} / \mathrm{ZnSOD}$ was mainly expressed in medial smooth muscle cells and it had a weak immunoreactivity in the endothelium. In the group with $\mathrm{Zn}$ supplementation diet (160 $\mathrm{mg} \mathrm{Zn/kg} \mathrm{lab} \mathrm{chow),} \mathrm{Cu} / \mathrm{ZnSOD}$ staining was more pronounced in the smooth muscle cells and endothelium, and the systolic blood pressure was significantly decreased $(p<0.05)$ in comparison with the groups fed with other $\mathrm{Zn}$ diets (40 or $60 \mathrm{mg} / \mathrm{kg}$ lab chow).

A functional relationship is found between zinc content in diet, activity of $\mathrm{Cu} / \mathrm{ZnSOD}$, arterial blood pressure and lipid profile. Diet with high zinc content $(160 \mathrm{mg} / \mathrm{kg})$ causes increase in the activity of $\mathrm{Cu} / \mathrm{ZnSOD}$, decreases the blood pressure and changes in lipid variables. Zinc supplementation $(160 \mathrm{mg} / \mathrm{kg})$ affects lipid profile by decreasing LDL and increasing HDL.

By immunohistochemistry, semiquantitative evaluation revealed that $\mathrm{Cu} / \mathrm{ZnSOD}$ was present in control group G1-40 $\mathrm{mg} \mathrm{Zn/kg} \mathrm{lab} \mathrm{chow,} \mathrm{in} \mathrm{G2-60} \mathrm{mg} \mathrm{Zn/kg} \mathrm{lab} \mathrm{chow} \mathrm{and} \mathrm{G3} \mathrm{-}$ $160 \mathrm{mg} \mathrm{Zn/kg} \mathrm{lab} \mathrm{chow,} \mathrm{but} \mathrm{its} \mathrm{expression} \mathrm{increased} \mathrm{ac-}$ cording to the $\mathrm{Zn}$ diets, reaching the highest level in G3 (diet with zinc supplementation).

\section{REFERENCES}

1. Cousins RJ. 1985. Absorption, transport and hepatic metabolism of copper and zinc: special reference to metalothionein and ceruloplasmin. Phys Rev 65: 238-309.

2. Di Silvestro R. 2000. Zinc in Relation To Diabetes and Oxidative Disease. J Nutr 130: 1509-11.

3. Friedewald W.T. et all. 1972 Clin Chem 18; Inc. $499 \mathrm{p}$.

4. Khoja SM, Marzouki ZM, Ashry KM et al. 2002. Effect of dietary zinc deficiency on rat lipid concentrations. Saudi Med J 23(1):82-6.

5. Marjani A. Plasma lipid peroxidation zinc and erythrocyte $\mathrm{Cu}-\mathrm{Zn}$-superoxide dismutase enzyme activity in patients with type 2 diabetes mellitus in Gorgan city (South East Of The Caspian Sea). 2005. The Internet Journal of Endocrinology 2:1.

6. Mertens A, Holvoet P. 2001. Oxidized LDL and HDL: antagonists in atherothrombosis. Faseb Journal 15:2073-2084.

7. Miller AF. 2004. Superoxide dismutases: active sites that save, but a protein that kills. Curr Opin Chem Biol 8 (2): 162-8.

8. Oteiza PL, Olin KL, Fraga CG, Keen CL. 1996. Oxidant defense systems in testes from zinc deficient rats. Proc Soc Exp Biol Med 213:85-91.

9. Sakanashi TM, Keen CL, Hong KH et al. 1993. Zinc deficiency associated alterations in the chemotactic and respiratory burst responses of rat peripheral blood neutrophils. FASEB J 7: A723.

10. Yagi K. Assay for serum and lipid peroxide level and its clinical significance. 1982. In: Yagi K (ed) Lipid peroxides in biology and medicine. Academic Press, Orlando, FL p. 223-243.

11. Yousef MI, E1-Hendy HA, E1-Demerdash FM et al. 2002. Dietary zinc deficiency induced-changes in the activity of enzymes and the levels of free radicals, lipids and protein electrophoretic behavior in growing rats. Toxicology 14:223-34. 